\title{
INVESTIGATION OF ANTIMICROBIAL PROPERTIES OF AQUEOUS EXTRACT OF LEMONGRASS (CYMBOPOGON CITRATUS) UNDER SOME PARAMETERS
}

Hajarat O. Yusuf*I and Joshua Olu

Address (es):

${ }^{1}$ National Biotechnology Development Agency, Environmental Biotechnology and Bioconservation Department, Along Musa Yar'adua Expressway, Airport Road,

Lugbe -Abuja, PMB 5118, Wuse Zone 3, Abuja, +2348066042543.

${ }^{2}$ Centre for Environmental Studies and Sustainable Development, Lagos State University, Ojo, Lagos.

*Corresponding author: haj_yusuf@yahoo.ca

ABSTRACT +20

https://doi.org/10.36547/be.2021.4.1.40-42

\section{ABSTRACT}

The antimicrobial effect of aqueous extract of lemongrass (Cymbopogon citratus) on some isolated microorganisms under varying parameters was investigated. Aqueous extract of lemongrass was prepared and its antimicrobial effect was evaluated against isolated bacteria (Staphylococcus aureus, Escherichia coli and Bacillus cereus) and fungi (Aspergillus flavus and Candida albicans) at varying temperature $\left(40,60\right.$ and $\left.80^{\circ} \mathrm{C}\right)$ and concentration $\left(10^{-1}, 10^{-2}, 10^{-4}, 10^{-8}\right.$ and $10^{-16}$ mol/ $\left./ \mathrm{L}\right)$ of the lemongrass aqueous extract shows that the extract was resisted by Escherichia coli, Bacillus cereus, Aspergillus flavus and Candida albicans. The aqueous $C$. citratus was able to inhibit the growth of Staphylococcus aureus and this inhibition increases as the concentration of the aqueous extract increase irrespective of the temperature of extraction. The aqueous extract of C. citratus is a tremendous antimicrobial substance especially towards Staphylococcus aureus.

Keywords: Lemongrass, Cymbopogon citratus, Antimicrobial, Aqueous extract, Staphylococcus aureus

\section{INTRODUCTION}

Lemongrass scientifically is known as Cymbopogon citratus and it belongs to the Poaceae family which counts more than 635 genera and 9000 species (Majewska et al., 2019). C. citratus is widely spread globally. More than 140 species of Cymbopogon, 52 of them grow in Africa, 45 in India, 6 in Australia, 6 in South America, 4 in Europe (only in Montenegro), 2 in North America, and the others in South Asia (Majewska et al., 2019). The genus Cymbopogon has been reviewed comprehensively in several articles (Avoseh $\boldsymbol{e t}$ al., 2015; Haque $\boldsymbol{e t}$ al., 2018).Nambiar and Matela (2012) reported that lemongrass grows well in both tropical and subtropical climates with around $900 \mathrm{~m}$ elevation. Ideal conditions for growing $C$. citrates are warm and humid climate with enough sunshine with temperature ranging from $20-30^{\circ} \mathrm{C}$ and rainfall between 250 and $330 \mathrm{~cm}$ annually. Moderately fertile soils and moderate irrigation has been proving to aid the growth of $C$. citratus and can also be grown on different kind of soils from loam to poor laterite (Nambiar and Matela, 2012).

In lemongrass pattern of growth shows cell division occurs at the apical meristem which usually encourage tiller growth, production of axillary buds follow and the emergence of new tillers. Tillering increases in a sigmoidal-shaped curve until the maximum tiller number is reached where the main culms may be difficult to distinguish from the tillers (Tajidin et al., 2012) C. citratus biological activity could be attribute to the essential oil and phenolic compounds such as phenolic acids, avonoids and tannins (Olorunnisola et al., 2014; Roriz et al., 2014; Tavares et al., 2015). Various chemical compounds of $C$. citratus essential oil has been to show some antimicrobial characteristics (Bassolé et al., 2011), deplete oxidants (Mansour et al., 2015), antiparasitic (Kpoviesi et al., 2014), insecticidal, and insect repellent actions (Brugger et al., 2019). Ekpenyong \& Akpan, (2017) has reported that lemongrass antimicrobial and antioxidant properties has be used for preservation of food as an alternative to chemical products. Avoseh et al., (2015) reported that $C$. citratus is applied in Nigeria for stomach upset, malaria treatment, insect repellent and as an antioxidant. In Eastern and Western India it is used for insecticides, cosmetics products, and for gastrointestinal disorders and fevers therapy (Desai. and Parikh, 2012).This study investigated the antimicrobial effect of aqueous extract of lemongrass $(C$. citratus) on some isolated microorganisms under varying parameters

\section{MATERIALS AND METHODS}

\section{Plant Material}

Lemongrass (Cymbopogon citratus) was obtained from the premises of Ahmadu Bello University post office main campus, Samara-Zaria and it was identified in Biological Sciences Herbarium Laboratory Department in Faculty of Science Ahmadu Bello University (ABU), Zaria.

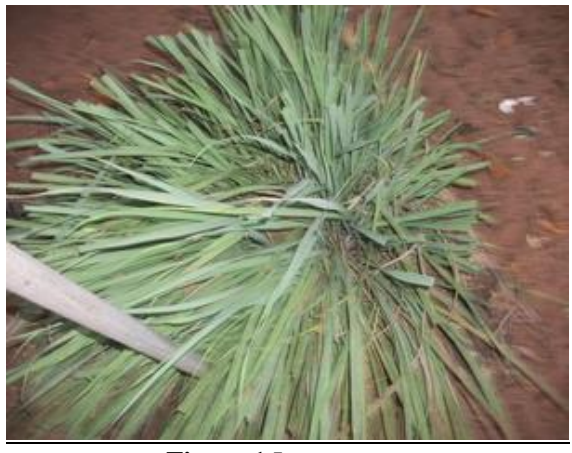

Figure 1 Lemongrass

Source of microbes

The microbial isolates (Staphylococcus aureus, Escherichia coli, Bacillus cereus, Aspergillus flavus and Candida albicans) used in this study were obtained from the Department of Microbiology ABU, Zaria.

\section{Proximate Analysis}

\section{Moisture and volatile matter determination}

$20 \mathrm{~g}$ of freshly cut lemon grass was weighed in clean dry and pre-weighed crucible. The fresh sample was oven dried at $70^{\circ} \mathrm{C}$ until a constant weight was attained. The drying sample is placed in a dessicator containing silica gel to cool before every successive weight remained constant.

$$
\% \text { Ash and moisture matter }=\frac{\text { loss in weight } \times 100}{\text { Initial weight of sample }}
$$

\section{Ash and organic dry matter determination}

Exactly $10 \mathrm{~g}$ of dried lemon grass was weighed in a crucible; it was then heated in a murffle furnace pre-set at $300^{\circ} \mathrm{C}$ for 2 hours and gradually rises to $500^{\circ} \mathrm{C}$ for 3 hours. The sample was removed and cooled in a dessicator after it has been completely ashed. Its weight was determined and percentage ash and organic dry matter was calculated.

$\%$ Ash and organic dry matter $=\underline{\text { loss in weight } \mathrm{x} 100}$ Initial weight of sample 


\section{Preparation of Aqueous extract of lemon grass}

$20 \mathrm{~g}$ grounded oven-dried lemon grass was poured in a pre-weighed thimble which was covered with a cotton wool and was dropped into the column of the soxhlet extractor. The extractor has been coupled to the pre-weighed $300 \mathrm{ml}$ round bottom flask known as quick fit containing $300 \mathrm{ml}$ sterile water. The quick fit and its content was placed on a heating mantle. The extraction was allowed to run for 6 hours at different temperatures of $40^{\circ} \mathrm{C}, 60^{\circ} \mathrm{C}$, and $80^{\circ} \mathrm{C}$ respectively in a given 3 samples and it was later autoclaved at $110^{\circ} \mathrm{C}$ for 20 minutes for sterility.

\section{Media preparation}

The media used to culture the organisms include nutrient agar (N.A) and potato dextrose agar (PDA) were prepared according to the manufacturer's specifications and sterilised by autoclaving at $121^{\circ} \mathrm{C}$ for 15 minutes. The media were cooled to $45^{\circ} \mathrm{C}$ and then poured into sterile petri-dishes and allowed to gel.

\section{Antimicrobial activity determination:}

\section{Bactericidal}

Three bacterial isolates: Staphylococcus aureus, Escherichia coli and Bacillus cereus were used and another three sets of plates in duplicates containing nutrient agar were inoculated with Staphylococcus aureus, Escherichia coli and Bacillus cereus using the spread plate technique.

A suction pump device was used to bore wells (six wells) according to the dilution of the extracts. Therefore $0.1 \mathrm{ml}$ of the serially diluted extracts with varying concentration in $\mathrm{mol} / \mathrm{L}$ was added to the wells as follows:

Well $1=10^{-1}$ Well $2=10^{-2}$.Well $3=10^{-4}$ Well $4=10^{-8}$ and Well $5=10^{-16}$

While well $6=$ control filled with only sterile distilled water. They were then incubated for 2 hours to allow diffusion to take place and finally incubated at $37^{\circ} \mathrm{C}$ for 24 hours.

\section{Fungicidal activity}

Two fungal isolated: Aspergillus flavus and Candida albicans were used and two sets of plates in duplets containing potato dextrose agar were inoculated with Aspergillus flavus and Candida albicans using the spread plate technique.

A suction pump device was used to bore wells (six wells) according to the dilution of the extracts. Therefore $0.1 \mathrm{ml}$ of the serially diluted extracts was added to the wells as follows:

Well $1=10^{-1,}$ Well $2=10^{-2}$, Well $3=10^{-4}$, Well $4=10^{-8}$ and Well $5=10^{-16}$

While well 6 was set as a control which was filled with sterile distilled water of $0.1 \mathrm{ml}$. The plate was left at room temperature for $24-48$ hours.

\section{RESULTS AND DISCUSSION}

\section{Proximate composition of lemongrass}

Table 1 Moisture and volatile matter determination:

\begin{tabular}{lll}
\hline Determination & \% of moisture content & \% of dry matter \\
\hline 1 & 68.00 & 32.00 \\
\hline 2 & 66.00 & 34.00 \\
\hline 3 & 65.70 & 34.30 \\
\hline Mean \pm S.D & $66.56 \pm 1.76$ & $33.43 \pm 1.76$ \\
\hline
\end{tabular}

Table 1 shows the moisture content of the lemongrass with $66.56 \%$, this simply explained that the plant contain high level of moisture

Table 2 Ash and organic dry matter determination:

\begin{tabular}{lll}
\hline Determination & \% of Ash dry matter & \% of organic dry matter \\
\hline 1 & 3.23 & 96.77 \\
\hline 2 & 2.00 & 98.00 \\
\hline 3 & 3.30 & 96.70 \\
\hline Mean \pm S.D & $2.84 \pm 1.03$ & $96.16 \pm 1.03$ \\
\hline
\end{tabular}

Table 2 indicate that Ash content of the plant is $2.84 \%$ and dry organic matter as $96.16 \%$
Cymbopogon citratus has been found to contain bioactive compounds that have been proven to have anti-oxidant, anxiolytic, anti-obesity, antihypertensive, bactericidal, fungicidal, anti-inflammatory, and antinociceptive (Moore-Neibel $\boldsymbol{e t}$ al., 2012; Olorunnisola et al., 2014).

\section{Antimicrobial activity determination}

Table 3 Extract at temperature of $40^{\circ} \mathrm{C}$, Concentration of extracts (double serial dilution method):

\begin{tabular}{llllllll}
\hline & $10^{-1}$ & $10^{-2}$ & $10^{-4}$ & $10^{-8}$ & $10^{-16}$ & Control \\
\hline Bacterial & & & & & & \\
\hline 1 & Escherichia coli & $\mathrm{R}$ & $\mathrm{R}$ & $\mathrm{R}$ & $\mathrm{R}$ & $\mathrm{R}$ & $\mathrm{RR}$ \\
\hline 2 & $\begin{array}{l}\text { Staphylococcus } \\
\text { aureus }\end{array}$ & $\mathrm{SS}$ & $\mathrm{S}$ & $\mathrm{SX}$ & $\mathrm{SX}$ & $\mathrm{SX}$ & $\mathrm{RR}$ \\
\hline 3 & Bacillus cereus & $\mathrm{R}$ & $\mathrm{R}$ & $\mathrm{R}$ & $\mathrm{R}$ & $\mathrm{R}$ & $\mathrm{RR}$ \\
\hline Fungal & & & & & & \\
\hline 1 & Aspergillus flavus & $\mathrm{R}$ & $\mathrm{R}$ & $\mathrm{R}$ & $\mathrm{R}$ & $\mathrm{R}$ & $\mathrm{RR}$ \\
\hline 2 & Candida albicans & $\mathrm{R}$ & $\mathrm{R}$ & $\mathrm{R}$ & $\mathrm{R}$ & $\mathrm{R}$ & $\mathrm{RR}$ \\
\hline
\end{tabular}

Keys: $\mathrm{R}=$ Resistant, $\mathrm{S}=$ Sensitive, $\mathrm{RR}=$ highly resistant, $\mathrm{SS}=$ highly sensitive, SX = slightly sensitive

In this study, the evaluation of the antimicrobial effect against isolated bacteria (Staphylococcus aureus, Escherichia coli and Bacillus cereus) and fungi (Aspergillus flavus and Candida albicans) at varying temperature and concentration of the lemongrass aqueous extract shows that the extract was resisted by Escherichia coli, Bacillus cereus, Aspergillus flavus and Candida albicans at temperature 40,60 and $80^{\circ} \mathrm{C}$. Also these five (5) microorganisms were resistance to the antimicrobial effect of the lemongrass aqueous extract at $10^{-1}, 10^{-2}, 10^{-4}, 10^{-8}$ and $10^{-16} \mathrm{~mol} / \mathrm{L}$ concentrations.

Table 4 Extract at temperature of $60^{\circ} \mathrm{C}$, Concentration of extracts (double serial dilution method)

\begin{tabular}{|c|c|c|c|c|c|c|}
\hline & $10^{-1}$ & $10^{-2}$ & $10^{-4}$ & $10^{-8}$ & $10^{-16}$ & Control \\
\hline \multicolumn{7}{|l|}{ Bacterial } \\
\hline Escherichia coli & $\mathrm{R}$ & $\mathrm{R}$ & $\mathrm{R}$ & $\mathrm{R}$ & $\mathrm{R}$ & RR \\
\hline $\begin{array}{ll}2 & \begin{array}{l}\text { Staphylococcus } \\
\text { aureus }\end{array} \\
\end{array}$ & SS & $S$ & $\mathrm{~S}$ & SX & SX & RR \\
\hline Bacillus cereus & $\mathrm{R}$ & $\mathrm{R}$ & $\mathrm{R}$ & $\mathrm{R}$ & $\mathrm{R}$ & RR \\
\hline \multicolumn{7}{|l|}{ Fungal } \\
\hline $1 \quad$ Aspergillus flavus & $\mathrm{R}$ & $\mathrm{R}$ & $\mathrm{R}$ & $\mathrm{R}$ & $\mathrm{R}$ & RR \\
\hline Candida albicans & $\mathrm{R}$ & $\mathrm{R}$ & $\mathrm{R}$ & $\mathrm{R}$ & $\mathrm{R}$ & $\mathrm{RR}$ \\
\hline
\end{tabular}

Keys: $\mathrm{R}=$ Resistant, $\mathrm{S}=$ Sensitive, $\mathrm{RR}=$ highly resistant, $\mathrm{SS}=$ highly sensitive, SX = slightly sensitive

Table 3, 4, and 5 shows that at different temperatures i.e. 40,60 and $80^{\circ} \mathrm{C}$, the aqueous $C$. citratus was able to inhibit the growth of Staphylococcus aureus and this inhibition increases as the concentration of the aqueous extract increase irrespective of the temperature of extraction. In like manner with this study, Nyamath and Karthikeyan (2018) among the six bacterial cultures tested with cold water, hot water and different solvents like ethanol andmethanol extracts of lemongrass the maximum zone of inhibition was observed in staphylococcus aureus.

Table 5 Extract at temperature of $80^{\circ} \mathrm{C}$, Concentration of extracts (double serial dilution method)

\begin{tabular}{|c|c|c|c|c|c|c|c|}
\hline & & $10^{-1}$ & $10^{-2}$ & $10^{-4}$ & $10^{-8}$ & $10^{-16}$ & Control \\
\hline \multicolumn{8}{|c|}{ Bacterial } \\
\hline 1 & Escherichia coli & $\mathrm{R}$ & $\mathrm{R}$ & $\mathrm{R}$ & $\mathrm{R}$ & $\mathrm{R}$ & $\mathrm{RR}$ \\
\hline 2 & $\begin{array}{l}\text { Staphylococcus } \\
\text { aureus }\end{array}$ & SS & SS & SS & $\mathrm{S}$ & $\mathrm{S}$ & $\mathrm{RR}$ \\
\hline 3 & Bacillus cereus & $\mathrm{R}$ & $\mathrm{R}$ & $\mathrm{R}$ & $\mathrm{R}$ & $\mathrm{R}$ & $\mathrm{RR}$ \\
\hline \multicolumn{8}{|c|}{ Fungal } \\
\hline 1 & Aspergillus flavus & $\mathrm{R}$ & $\mathrm{R}$ & $\mathrm{R}$ & $\mathrm{R}$ & $\mathrm{R}$ & $\mathrm{RR}$ \\
\hline 2 & Candida albicans & $\mathrm{R}$ & $\mathrm{R}$ & $\mathrm{R}$ & $\mathrm{R}$ & $\mathrm{R}$ & $\mathrm{RR}$ \\
\hline
\end{tabular}

Keys: $\mathrm{R}=$ Resistant, $\mathrm{S}=$ Sensitive, $\mathrm{RR}=$ highly resistant, $\mathrm{SS}=$ highly sensitive, $\mathrm{SX}=$ slightly sensitive 
It had been proposed that the phytochemicals such as alkaloids, tannis, flavanoids, terpenes and phenolic compounds. Phenols and flavonoids found in C. citratus causes disruption of the membrane and affect their hereditary information (Adegbegi et al., 2012; Bhoj et al., 2011; Gopinath et al., 2013; Jayashree et al., 2013).

\section{CONCLUSION}

Cymbopogon citratusis no doubt of a plant that has been shown to possess antimicrobial values by different studies and of which this study has joined in upholding this claim. The aqueous extract of $C$. citratus is very active in inhibiting the growth of Staphylococcus aureus as the concentration of the extract increases.

Acknowledgments: Many thanks to the Ahmadu Bello University, Zaria Microbiology laboratory staffs for their assistance in course of this research.

\section{REFERENCES}

ADEGBEGI, A.J., USUNOBUN, U., ADEWUMI, B.L. 2012. Comparative studies on the chemical composition and antimicrobial activities of the ethanolic extracts of lemongrass leaves and stems. Asian Journal of Medical Sciences 4(4), 145-148. https://maxwellsci.com/print/ajms/v4-145-148.pdf

AVOSEH, O., OYEDEJI, O., RUNGQU, P. NKEH-CHUNGAG, B., OYEDEJI, A. 2015. Cymbopogon Species; thnopharmacology, Phytochemistry and the Pharmacological Importance. Molecules 20, 7438-7453. http://dx.doi.org/10.3390/molecules20057438

BASSOLÉ, I.H.N., LAMIEN-MEDA, A., BAYALA, B., OBAME, L.C., ILBOUDO, A.J., FRANZ, C., NOVAK, J., NEBIÉ, R.C., \& DICKO, M.H. (2011). Chemical composition and antimicrobial activity of Cymbopogon citratus and Cymbopogon giganteus essential oils alone and in combination. Phytomedicine, 18(12), 1070-1074 https://doi.org/10.1016/j.phymed.2011.05.009 BHOJ, R.S., VIDYA, S., RAJ, K.S., EBIBENI, N. 2011. Antimicrobial activity of lemongrass (Cymbopogon citratus) oil against microbes of environmental, clinical and food origin. International Research of Pharmacy and Pharmacology, 1(9), 228-236. https://www.interesjournals.org/articles/antimicrobial-activity-oflemongrass-cymbopogon-citratus-oil-against-microbes-of-environmental-

clinical-and-food-origin.pdf

BRUGGER, B.P., MARTINEZ, L.C., PLATA-RUEDA, A., CASTRO, B.M.D.E., SOARES, M.A., WILCKEN, C.F., CARVALHO, A.G., SERRAO, J.E., ZANUNCIO, J.C. 2019. Bioactivity of the Cymbopogon citratus (Poaceae)essential oil and its terpenoid constituents on the predatory bug, Podisus nigrispinus (Heteroptera: Pentatomidae). Scientific Reports, 9, art. no. 8358. https://www.nature.com/articles/s41598-019-44709-y

DESAI, M.A., PARIKH, J. 2012. Microwave assisted extraction of essential oil from Cymbopogon flexuosus (Steud.) wats: A parametric and comparative study. Sep. Sci. Technol. 47, 1963-1970 https://doi.org/10.1080/01496395.2012.659785 EKPENYONG, CH.E., AKPAN, E.E. 2017. Use of Cymbopogon citratus essential oil in food preservation: Recent advances and future perspectives. Critical Reviews in Food Science and Nutrition, 57(12), 2541-2559. https://doi.org/10.1080/10408398.2015.1016140

HAQUE, A.N.M.A., RAMADEVI, R., NAEBE, M. 2018. Lemongrass (Cymbopogon): a review on its structure, properties, applications and recent developments. $\quad$ Cellulose, 25(10), 5455-5477. https://www.springerprofessional.de/en/lemongrass-cymbopogon-a-review-onits-structure-properties-appli/15992922

KPOVIESSI, S., BERO, J., AGBANI, P., GBAGUIDI, F., KPADONOU-KPOVIESSI, B., SINSIN, B., Accrombessi, G., Frederich, M., Moudachirou, M., Quetin-Leclercq, J. (2014). Chemical composition, cytotoxicity and in vitro antitrypanosomal and antiplasmodial activity of the essential oils of four Cymbopogon species from Benin. Journal of Ethnopharmacology, 151(1), 652659. https://doi.org/10.1016/j.jep.2013.11.027

MAJEWSKA, E., OWSKA, M.K.,, KOWSKA, E.G.S., KOWALSKA, D., TARNOWSKA, K. 2019. Lemongrass (Cymbopogon citratus) Essential Oil: Extraction, Composition, Bioactivity and Uses for Food Preservation - A Review. Pol. J. Food Nutr. Sci., 69(4), 327-341. http://dx.doi.org/10.31883/pjfns/113152 MANSOUR, A.F., FIKRY, R.M., SAAD, M.M., MOHAMED, A.M. 2015. Chemical composition, antioxidant and antimicrobial activity of (Cymbopogon citratus) essential oil cultivated in Madinah Monawara, Saudi Arabia and its comparison to the Egyptian chemotype. International Journal of Food and
Nutritional Sciences, 4(4), 29-33. https://www.ijfans.org/article.asp?issn=23191775 ; year $=2015 ;$ volume $=4 ;$ issue $=4 ;$ spage $=29 ;$ epage $=33$; aulast $=$ Mansour $;$ type $=0$ MOORE-NEIBEL, K., GERBER, C., PATEL, J., FRIEDMAN, M., RAVISHANKAR, S. 2012. Antimicrobial activity of lemongrass oil against Salmonella enterica on organic leafy greens. Journal of Applied Microbiology, 112(3), 485-492. https://doi.org/10.1111/j.1365-2672.2011.05222.x

NAMBIAR, V.S., MATELA, H. 2012. Potential Functions of Lemon Grass (Cymbopogon citratus) in Health and Disease. International Journal of Pharmaceutical \& Biological Archives, 3(5), 1035-1043. https://www.researchgate.net/publication/234007840 Potential Functions of Le mon_Grass_Cymbopogon_citratus_in_Health_and_Disease

NYAMATH, S., KARTHIKEYAN, B. 2018. In vitro antibacterial activity of lemongrass (Cymbopogon citratus) leaves extract by agar well method. Journal of Pharmacognosy and Phytochemistry, 7(3), 1185-1188. https://www.phytojournal.com/archives/?year=2018\&vol=7\&issue $=3 \&$ ArticleId $=4324$

OLORUNNISOLA, S.K., ASIYANBI, H.T., HAMMED, A. M., \& SIMSEK, S. 2014. Biological properties of lemongrass: An overview. International Food Research Journal, 21(2), 455-462. http://www.ifrj.upm.edu.my/21\%20(02)\%202014/4\%20IFRJ\%2021\%20(02)\%20 2014\%20043.pdf

RORIZ, C.L., BARROS, L., CARVALHO, A.M., SANTOS-BUELGA, C., FERREIRA, I.C.F.R. 2014. Pterospartum tridentatum, Gomphrena globosa and Cymbopogon citratus: A phytochemical study focused on antioxidant compounds. Food Research International, 62, 684-693. https://doi.org/10.1016/j.foodres.2014.04.036

TAJIDIN, N. E., AHMAD, S. H, ROSENANI, A. B., AZIMAH, H., MUNIRAH, M. 2012. Chemical composition and citral content in lemongrass (Cymbopogon citratus) essential oil at three maturity stages. African Journal of Biotechnology 11(11), 2685-2693. https://doi.org/10.5897/AJB11.2939 